\title{
Aplikácia metód kognitívneho výskumu na hraniciach literatúry a filmu: Ted Chiang - Príbeh tvojho života a jeho konceptuálne metafory
}

Peter Getlík (Košice)

\begin{abstract}
Abstrakt
Štúdia prezentuje aktuálne metodologické perspektívy interdisciplinárneho výskumu literatúry na hraniciach s audiovizuálnym médiom, ked’ prepája štúdium adaptácií a kognitívny literárnovedný prístup. Toto spojenie vzniká v neoformalistickej tradícii, ktorá zdôrazňuje často opomínanú motivovanost' umeleckého znaku v celom (technickom aj kognitívnom) procese jeho vzniku. Príspevok najprv objasní, kde a prečo sa vytvára metodologický priestor pre kognitívny prístup k adaptáciám, a následne ponúkne prípadovú štúdiu poviedky Príbeh tvojho života od Teda Chianga a jeho filmovej adaptácie Prvý kontakt s aplikáciou interdisciplinárnej metódy.
\end{abstract}

\section{Kl'účové slová}

Ted Chiang; adaptácia; konceptuálna metafora; teleologický; Fermatov princíp

\section{Abstract \\ Application of Cognitive Research Methods at the Boundaries of Literature and Film: Ted Chiang - The Story of Your Life and Its Conceptual Metaphors}

The study presents current methodological perspectives of interdisciplinary research on literature at the borders with the audiovisual medium, combining the adaptation studies and the cognitive literary approach. This combination merged through neoformalist tradition, which emphasizes the often neglected motivation of the artistic sign in the whole (technical and cognitive) process of its origin. Paper will explain where and why the methodological milieu for a cognitive approach to adaptations arises, and then offer a case study of The Story of Your Life by Ted Chiang and its film adaptation Arrival with the aplication of interdiciplinary method.

\section{Key words}

Ted Chiang; adaptation; conceptual metaphor; teleological; Fermat's principle

Príspevok je súčastou riešenia projektu APV-19-0244 Metodologické postupy v literárnovednom výskume s presahom do mediálneho prostredia. 


\section{Úvod}

Cielom našej štúdie je overit prínos kognitívneho prístupu vo výskume adaptácií literárnych diel, ktorý môže byt účinným nástrojom pri odhal'ovaní nadinterpretácií umeleckého znaku. Uvedený ciel' budeme naplňat (1) v rovine metodologickej, ked' zhrnieme východiská nášho variantu kognitívneho prístupu a (2) v rovine analytickej, ked’ overíme jeho praktické možnosti a ohraničenia:

1) Stručne predstavíme metodologické východiská interdisciplinárneho priestoru v samostatnej kognitívnej tradícii literatúry a filmu a objasníme, kde a prečo vzniká potreba kognitívneho prístupu v oblasti adaptácií. Zadefinujeme pozíciu kognitívneho prístupu v kontexte rôznych oblastí adaptológie, a to najmä v súvislosti s najspornejším problémom vernosti voči originálu. Zdôvodníme výber metatextuálnej výskumnej vzorky.

2) Predložíme interpretáciu poviedky Príbeh tvojho života (The Story of Your Life) a jeho filmového spracovania Prvý kontakt ${ }^{2}$ (Arrival) v úzkej komparácii s odlišnými interpretačnými postupmi. Pomocou analýz konceptuálnych metafor budeme posudzovat text a jeho interpretácie ${ }^{3} \mathrm{~s}$ cielom odhalit prípadné nadinterpretácie na úrovni nereflektovaných metaforických prienikov medzi umeleckým textom a jeho interpretáciou. Analýzu podporíme aj v širšom kontexte Chiangovho diela. V adaptácii, ktorá sa snaží o podobnosṫ s originálom, sa pokúsime identifikovat jednotný konceptuálny základ centrálnych metafor, vd’aka čomu by sme mohli rozpoznat eventuálne nadinterpretácie.

V závere zhodnotíme, či sú praktické možnosti kognitívneho prístupu pri odhalovaní nadinterpretácií umeleckého znaku prínosné v našom vopred vymedzenom metodologickom priestore.

\section{Prepojenie metodológie kognitívneho výskumu literatúry a adaptačných štúdií}

Súčasný kognitívny prístup k literatúre na Slovensku ${ }^{4}$ nadviazal na už ustálenú svetovú ${ }^{5}$ tradíciu a vd’aka jeho variáciám vo filmových štúdiách ${ }^{6}$ vznikla silná východisková pozí-

1 CHIANG, Ted: Pribehy vášho života. Bratislava: Premedia, 2017, s. 88-138.

2 VILLENEUVE, Denis: Proý kontakt [Film]. Los Angeles, CA, 2016. 117 min.

3 NOLETTO, Israel A. C. - LOPES, Sebastião Alves Teixeira: Heptapod B and the Metaphysics of Time - Hybrid Interfaces of Literature, Cinema and Science. Polifonia 25, 2018, č. 40.2, s. 206-221.

4 Kompaktnejší pohlad slovenských (ale okrajovo aj českých) autorov možno nájsț v: KUZMÍKOVÁ, Jana (ed.): Literatúra v kognitívnych súvislostiach. Bratislava: Ústav slovenskej literatúry SAV, 2014.

5 Výrazný vplyv majú práce Turnera či Stockwella: TURNER, Mark: The Literary Mind. New York: Oxford University Press, 1996; STOCKWELL, Peter: Cognitive Poetics: An Introduction. New York: Routledge, 2002.

6 Kognitívnu tradíciu vo výskume filmu intenzívne usmerňoval Buckland, v súčasnosti aj Brylla a Kramerová: BUCKLAND, Warren: The Cognitive Semiotics of Film. Cambridge: Cambridge University Press, 2000; BRYLLA, Catalin - KRAMER, Mette (eds.): Cognitive Theory and Documentary Film. London: Palgrave Macmillan, 2018. 
cia tejto perspektívnej vetvy výskumu aj v prienikovej oblasti adaptáciîn. Náš príspevok rámcovo vychádza z Thomasa Leitcha ${ }^{8}$, ktorý rezumuje diskurz v interdisciplinárnej oblasti adaptácií a kriticky zorad’uje pätnást’ súčasných adaptologických otázok podla ich vedeckého potenciálu. Poradie prístupov možno sledovat na Leitchovej implicitnej osi, kde za menej efektívne považuje tie, ktoré zdiel’ajú axiologickú premisu privilegovanosti literatúry a hodnotia vernost̉ adaptácie voči originálu. Prístupy, ktoré Leitch radí k tým konštruktívnejším, považujú (ne)vernost̉ voči originálu za jav, ktorý nie je vel’mi relevantný a nemal by byt súčastou hodnotenia adaptácie. Tieto výskumy sa zameriavajú napríklad na to, že podoba adaptačného procesu môže mat implikácie vo všeobecnejších teóriách intertextuality, ale tiež pomáhajú vysvetlit metatextové vrstvy sebareflektujúcich adaptácií alebo modifikujú súčasné modely adaptácie.

Potrebu efektívnosti interdisciplinárneho výskumu, ktorej sa dovoláva Leitch, možno ilustrovat’ aj v disproporcii medzi najčastejšími (a stále pribúdajúcimi) štúdiami - ich výstupom je nezriedka vyčerpávajúce porovnanie adaptácie a originálu s výsledným hodnotiacim súdom o kvalite prekladu - a deviatimi možnými oblastami záujmu teórie adaptácie, ktoré rozpoznávajú Cartmellová a Whelehanová9. Vernost̉ voči originálu je teda v kontexte iných oblastí adaptológie zbavená svojej predchádzajúcej privilegovanosti a aj v súlade s Leitchovými názormi môžeme uvieste, že viacerí poprední literárni a filmoví vedci $^{10}$ (aj etablovaní adaptológovia) sa v oblasti adaptácií snažia od diskurzu o vernosti (fidelity) dištancovat'. Menej sa venujú tomu, v čom sa diela podobajú, ale naopak programovo upriamujú pozornost’ na ich odlišnosti. V uvedenom smere je progresívny výskum transkultúrnych adaptácií alebo revízií, v ktorých sa odhal’ujú najčastejšie sexistické, koloniálne alebo iné historické či ideologické vrstvy, s ktorými sa adaptácie snažia umelecky vysporiadat'. V našom kultúrnom prostredí sa progresívna línia adaptológie centralizuje najmä v zásadných prácach Petra Bubeníčka ${ }^{11}$, ktorý skúma subverzívne adaptácie vymaňujúce sa spod tlakov bývalého socialistického režimu.

$7 \quad \mathrm{~V}$ poslednej poldekáde registrujeme v popredných adaptologických periodikách vzrastajúci počet aspoň parciálne kognitívnych prístupov k adaptácii.

8 LEITCH, Thomas: Adaptation Studies at a Crossroads. Adaptation 1, 2008, č. 1, s. 63-77.

9 CARTMELL, Deborah - WHELEHAN, Imelda: Screen Adaptation: Impure Cinema. London: Palgrave Macmillan, 2010, s. 15.

10 Robert Stam, Alessandra Raengová, Julie Sandersová či Linda Hutcheonová sa prikláňajú skôr k viacdimenzionálnym modelom bez kritického hodnotenia vernosti, ktoré sú konzistentnejšie s chápaním intertextuality Julie Kristevovej. Porov. HUTCHEON, Linda: A Theory of Adaptation. New York: Routledge, 2006; KRISTEVA, Julie: Desire in Language: A Semiotic Approach to Literature and Art. New York: Columbia University Press, 1980; SANDERS, Julie: Adaptation and Appropriation (The New Critical Idiom). New York: Routledge, 2005; STAM, Robert - RAENGO, Alessandra (eds.): A Companion to Literature and Film. Oxford: Blackwell Publishing Ltd, 2004.

11 BUBENÍČEK, Peter: Subversive Adaptations: Czech Literature on Screen behind the Iron Curtain. London: Palgrave Macmillan, 2017. 


\section{Definovanie vlastností predstaveného kognitívneho prístupu pri skúmaní adaptácie}

Hermanssonová12 (aj v nadväznosti na Leitcha, Cartmellovú a Whelehanovú) vo svojej provokatívnej metodologickej štúdii o probléme vernosti uvádza, že súčasná propagovaná paradigma zacielená na revízie je síce produktívnou oblastou výskumu, no iba zdanlivo sa zbavuje porovnávania s originálom, ked’ ho rieši v negatívnych formuláciách revízií. Preto, aj ked' je v našom kognitívnom prístupe $\mathrm{k}$ adaptáciám problém vernosti periférny, nesnažíme sa ho ignorovat, ale prepájame ho s oblastami výskumu, ktoré sú tradične späté s kognitívnym prístupom. Výhodou kognitívneho prístupu k adaptáciám je, že pomocou výskumu konceptuálnej metafory, na ktorú upriamujú pozornosṫ Lakoff s Johnsonom ${ }^{13}$, možno zdanlivo vzdialené oblasti (kolektívnej aj individuálnej) recepcie na jednej strane a vernosti voči originálu na druhej, objasňovał̉ súčasne. Vernost̉ teda nepoužívame ako hodnotiace kritérium adaptácií, ale ako indikátor pravdepodobnej koherencie jednotlivých konceptuálnych metafor.

Predpokladom uplatnenia kognitívneho prístupu je prijatie hypotézy vtelenej mysle (embodied mind): je vhodné revidovat descartovské delenie tela a mysle, ako to robia Lakoff s Johnsonom ${ }^{14} \mathrm{v}$ aktualizácii pohladov na tradičnú filozofiu cez priezor poznatkov kognitívnej vedy. Lakoff s Nunezom ${ }^{15}$ skúmajú aj pohlad na metaforické štruktúry v matematike, čo treba mat na pamäti aj pri nadchádzajúcej analýze fyzikálnych metafor v literárnom texte, ktorej sa budeme venovat̉ v druhej časti našej štúdie. Vyčerpávajúci výklad podporujúci revíziu descartovského delenia tela a mysle ponúka Bergen ${ }^{16}$, ked' zosumarizuje množstvo empirických štúdií z oblasti psychológie, neurovedy či vývoja umelej inteligencie, ktoré predkladajú primerané základy na akceptovanie hypotézy vtelenej ludskej mysle.

V našom variante prieniku kognitívneho prístupu $\mathrm{k}$ literatúre a filmu nie je výber analyzovaných diel arbitrárny - ako súčasný stav takmer neobmedzeného generovania navzájom zastupitelných štúdií o vernosti ostro kritizuje Leitch ${ }^{17}$. Je efektívne preferovat diela s výraznými metatextovými kvalitami. Empiricky zodpovedné štúdie sú schopné štylisticky priznaným spôsobom odprezentovat vlastné metaforického podložie, ktoré aj metatextovo ilustruje (v našom prípade metodologický) problém. Otázky, ktoré me-

12 HeRMANSSON, Casie: Flogging Fidelity: In Defense of the (Un)Dead Horse. Adaptation 8, 2015, č. 2, s. $147-160$.

13 LAKOFF, George - JOHNSON, Mark: Metaphors We Live By. Chicago: The University of Chicago Press, 2003.

14 LAKOFF, George - JOHNSON, Mark: Philosophy in the Flesh: the Embodied Mind E its Challenge to Western Thought. New York: Basic Books, 1999.

15 LAKOFF, George - NUNEZ, Rafael E.: Where Mathematics Come From: How The Embodied Mind Brings Mathematics Into Being. New York: Basic Books, 2001.

16 BERGEN, Benjamin K.: Louder than words: the new science of how the mind makes meaning. New York: Basic Books, 2012.

17 LEITCH, Thomas: Adaptation Studies at a Crossroads. Adaptation 1, 2008, č. 1, s. 65. 
tatextovo o sebe kladú aj adaptácie, navyše už Leitch ${ }^{18}$ vo svojom zozname považuje za jedny z najzaujímavejších. Výber našej výskumnej vzorky preto má svoje opodstatnenie aj v súčasnej praxi v oblasti adaptácií literárnych diel. Vd’aka nemu možno upozorňovat na intersubjektívny charakter nášho výskumu vyplývajúci z uplatnených metafor, ktoré sa v texte budú inherentne nachádzat. Ako ukážeme v nadchádzajúcej analýze, práve prehliadanie vlastných konceptuálnych metafor využitých pri interpretácii umeleckého diela môže smerovat k neúmyselným nadinterpretáciám textu a unáhleným súdom o zámeroch autora.

\section{Konceptuálne metafory v literárnom diele a jeho filmovej adaptácii}

Adaptácia Pruý kontakt, ktorú scenáristicky spracoval pre film Eric Heisserer a režíroval Denis Villeneuve, metatextovo napíňa viacero našich preferovaných kritérií práve vd’aka forme prekladu konceptuálnych metafor do audiovizuálnej podoby. Autorom literárnej predlohy Príbeh tvojho života je Ted Chiang, ktorý priznáva inšpirácie v klasických sci-fi dielach, Borgesových textoch a lingvistických štúdiách. V analyzovanej poviedke je zrejmá symbióza východísk prírodných vied (fyziky a biológie) a humanitných vied (lingvistiky a literárnej vedy) - hlavnými postavami sú totiž fyzik Gary Donnelly a lingvistka Louise Banksová.

Premisou Chiangovho literárneho diela je, že prvým krokom po príchode mimozemskej civilizácie heptapodov s radikálne odlišnou fyziológiou - majú radiálne symetrické telá (podobne ako medúzy), čo podmieňuje ich nelineárny jazyk - nebude žánrovo štandardná výmena technológie či smrtel’ných guliek, ale náročné nadviazanie komunikácie. Jednou z centrálnych tém netradičného sci-fi diela je teda jazyk. Chiang pracuje so Sapirovou-Whorfovou lingvistickou hypotézou, že jazyk, ktorým hovoríme, formuje naše vedomie. Sapirova-Whorfova hypotéza historicky predchádza modernej kognitívnej hypotéze vtelenej mysle. Aby sme sa sami pokúsili aspoň čiastočne vyvarovat interpretačnému posunu, na ktorý neskôr upozorníme v našej analýze, zdá sa nám vhodné poukázat' na konceptuálne prieniky oboch hypotéz. Lakoff ${ }^{19}$ zdôrazňuje ich rozdiely v revízii Whorfianovho relativizmu, ktorý ešte nie je v plnej miere konzistentný s neskoršími empirickými dôkazmi. Koncepty vplyvu jazyka na myslenie v našej štúdii sledujeme v rovine metodologickej i v rovine analyzovaného textu: nelineárny jazyk heptapodov v poviedke súvisí s ich cyklickým a teleologickým vnímaním udalostí, ktoré je umelecky stavané do kontrastu k lineárnemu jazyku ludí a ich primárne kauzálnemu chápaniu udalostí.

Ted Chiang rozvíja svoju poviedku na pozadí teleologicko-fyzikálnej konceptuálnej metafory o predpokladaných metafyzických vlastnostiach svetla, ktorú odvodzuje zo starších interpretácií Fermatovho princípu: SVETLO JE ENTITA. Základom uvedenej

18 Ibidem, s. 67.

19 LAKOFF, George: Women, Fire and Dangerous Things: What Categories Reveal About the Mind. Chicago: University of Chicago Press, 1990, s. 304-337. 
metafory u Chianga je, že „lúč svetla sa vždy šíri najrýchlejšou možnou cestou“20, alebo: „Lepšie povedané, svetlo sa vždy šíri po extrémnej dráhe, takže to trvá bud' minimálny, alebo maximálny čas" ${ }^{\text {"1 }}$. Chiang ponúka vo svojom texte ešte podrobnejší výklad, no pre náš výskum nie je nevyhnutná rozsiahla explikácia fyzikálneho javu. Primárne upriamime pozornost na jeho metaforickú interpretáciu.

Metafora SVETLO JE ENTITA sa upevňuje vd’aka vlastnostiam, ktoré sú prekvapivé v kontraste k chápaniu tradičnej karteziánskej mechaniky. Svetlo sa javí ako entita nepohybujúca sa na základe pravidiel kauzality, lebo v teleologickom zmysle „vie“, kam dopadne, skôr, než sa tak stane. Svoju trajektóriu efektívne upravuje, aby sa čas tejto „púte“ minimalizoval (alebo maximalizoval). V rámci logiky danej konceptuálnej metafory sa zdá, že svetlo koná a jeho konanie je dokonca nadprirodzene prezieravé. Jadro konceptuálnej metafory nie je Chiangovým výmyslom, rovnako ako filozofické implikácie tohto javu, za ktoré Fermata kritizovali ${ }^{22}$ descartovci, pretože sa zdalo, že nabáda na priznanie vedomia a zámeru prírodným javom. Chiang na metafore SVETLO JE ENTITA vybudoval zaujímavý fiktívny svet, pretože, ako sa v jeho poviedke ukáže, mimozemskí heptapodi pri pokusoch o nadviazanie komunikácie s l’ud’mi nereagujú na jednoduché algebraické výrazy, ale na ukážky Fermatovho princípu, ktorý má komplikované matematické vyjadrenia.

Chiang si predstavuje heptapodov so siedmimi očami vôkol hlavy. Nemajú rovnaký koncept pre „vpredu“ a „vzadu“ ako l'udia, pretože všetko čo vidia, je naraz vôkol nich (v minimálnej až maximálnej vzdialenosti). Ako ukazujú Lakoff s Johnsonom²3, orientačné metafory patria v hierarchii konceptuálnych metafor k tým, ktoré majú primárne postavenie pri formovaní myslenia. Fyziológia tiel heptapodov predpokladá radikálne odlišné životné podmienky ich vzniku a zároveň predurčuje odlišné kognitívne schopnosti, pre ktoré je „vpredu“ a „vzadu“ či „predtým“ a „potom“ naraz a na jednom mieste. Premýšlanie heptapodov sa odzrkadluje v písanej podobe ich simultánneho jazyka vizuálnych semagramov: „Vyzerali ako imaginárne modlivky nakreslené písaným pismom, túliace sa $k$ sebe a vytvárajúce escheriánske štruktúry, pričom každá bola trochu iná. Najdlhšie vety zas mali podobný efekt ako psychedelické plagáty: niekedy pôsobili rozmazaným dojmom, inokedy zas hypnotizovali" ${ }^{24}$.

\section{Analýza metafyzickej nadinterpretácie Chiangovej fyzikálnej metafory}

V súlade so Sapirovou-Whorfovou hypotézou Chiang ilustruje, ako je symetrické telo, symetrický jazyk a časovo symetrické premýšlanie heptapodov prepojené. Majú problé-

20 CHIANG, Ted: Príbehy vášho života. Bratislava: Premedia, 2017, s. 113.

21 Ibidem, s. 114.

22 LARANJIRAS, C'assio C. - da SILVA, Jojomar L. - CHIAPPIN, J. R. N.: The heuristics of representation in science: the mechanisms and mathematical principles in physics of Descartes and Fermat. Revista Brasileira de Ensino de Física 39, 2017, č. 4, s. 1-15.

23 LAKOFF, George - JOHNSON, Mark: Metaphors We Live By. Chicago: The University of Chicago Press, 2003, s. 15.

24 CHIANG, Ted: Príbehy vášho života. Bratislava: Premedia, 2017, s. 108. 
my s „ludským“ kauzálnym vnímaním, lineárnym jazykom či algebrou, no zároveň majú kognitívne schopnosti, ktoré sú pre človeka vzdialené, a teda svet vnímajú absolútne teleologicky, ich jazyk je simultánny a variačné princípy ako Fermatov princíp sú pre nich úplne samozrejmé. Vd’aka temporálne nekonzistentnému rozprávaniu Louise Banksovej sa čitatel’ dozvedá, ako sa proces učenia simultánneho jazyka heptapodov podpisuje na jej kognitívnych schopnostiach, ked' sa aj v jej mysli naraz mieša minulost', prítomnost i budúcnost.

Chiang sa pokúša zaviest’ fantastickú fyzikálnu premisu, aby vytvoril pravdepodobnú kvázi vedeckú paralelu k teleologickému vnímaniu heptapodov v postupnosti:

A. SVETLO JE ENTITA (vykazuje znaky podobné l'udskému správaniu),

B. SVETLO JE ENTITA S NADLUDSKÝMI SCHOPNOSŤAMI (pozná budúcnost').

Ak čitatel' akceptuje premisu, že svetlo môže vidiet’ do budúcnosti, môže akceptovat aj nadväzujúce obrazy, v ktorých je heptapod entita s podobnými nadludskými schopnostami, ako má svetlo. Cez odprezentovanú Sapirovu-Whorfovu hypotézu sa prepojí aj to, že človek si danú schopnosṫ môže osvojit’ učením sa jazyka heptapodov, lebo sama osebe akoby v epifenomenálnej logike nebola nadprirodzená.

Konzistencia Chiangových metafor teda vyplýva z konkrétnej interpretácie Fermatovho princípu, lenže aj jazyk prírodných vied je inherentne metaforický a okrem metafory SVETLO JE ČASTICA, ktorá podporuje staršiu teleologickú interpretáciu Fermatovho princípu, je známa aj novšia metafora SVETLO JE VLNA alebo SVETLO JE ČASTICA-VLNA ${ }^{25}$ (resp. správa sa ako častica i vlna zároveň). Redukcia súčasnej komplexnejšej časticovo-vlnovej metafory svetla na staršiu metaforu častice je, samozrejme, oprávneným literárnym postupom, ktorý Chiang využíva na svoj poetický zámer, no ak pristúpime k redukcii tejto metafory aj v literárnovednom výskume, je pravdepodobné, že aj interpretácia poetického zámeru autora bude posunutá. K spomínanému posunu dochádza v štúdii Noletta a Lopesa ${ }^{26}$, ktorí analyzujú prieniky literatúry, filmu a vedy v diele Teda Chianga a jeho filmovej adaptácie.

Noletto a Lopes pracujú pri analýze Chiangovho textu s interpretáciou Fermatovho princípu iba v jeho redukovanej forme, čím sa zjednodušuje (až nerešpektuje) aj Chiangov poetický zámer. Pri svojej analýze používajú len metafory, ktoré sú konzistentné s konceptuálnou metaforou SVETLO JE ENTITA a vyvodzujú, že Chiang sa vo svojom diele snaží poukazovat na teleologickú podstatu sveta. Je evidentné, že konceptuálna teleologická metafora v umeleckom texte je konzistentná so závermi Noletta a Lopesa ${ }^{27}$, hoci tie sú v dôsledku redukcie spochybnitel'né. Metafora predmetu analýzy a pohlad výskumníkov sa zhoduje natol'ko, že sami autori prinášajú d’alšie komplexné metafory, ktorými objasňujú predpokladané teleologické vlastnosti prírodného javu. Napríklad

25 Zlučovanie metafor (blending) radí Turner ku komplexným operáciám, ktoré vytvárajú významy. Porov. TURNER, Mark: The Literary Mind. New York: Oxford University Press, 1996, s. 57.

26 NOLETTO, Israel A. C. - LOPES, Sebastião Alves Teixeira: Heptapod B and the Metaphysics of Time - Hybrid Interfaces of Literature, Cinema and Science. Polifonia 25, 2018, č. 40.2, s. 206-221.

27 „By the way, in case it has not been made sufficiently clear by now, Fermat's principle of least time is a metaphor used by the author to show that the epiphenomena in nature are deterministic and seek for accomplishing purposes, rather than being merely causal." Ibidem, s. 219. 
posilňujú konceptuálnu metaforu SVETLO JE ENTITA, ked' hovoria ${ }^{28}$ o šoférovi, ktorý svoju cestu podla premávky mení konzistentne s princípmi kauzality, v kontraste ku svetlu, ktoré „pozná“ budúcnost a svoju trajektóriu už vopred efektívne „plánuje“.

Kognitívny prístup k textu a vnímanie metaforickej podstaty rôznych štylistických podôb jazyka pripravuje interpretátora na skutočnost', že všetky definície (filozofické aj fyzikálne), ktorými bude parciálne objasňovat literárne javy, sú inherentne metaforické. Východiskom teda nie je zbavovanie sa metaforickosti v akademickom jazyku, ale naopak odhal'ovanie obraznosti literárneho diela paralelne s upozorňovaním na limity vlastných konceptuálnych metafor, ktoré nevznikajú arbitrárne, ale sú preukázatel'ne motivované.

Uvedený problém sa u Noletta a Lopesa umocňuje aj výrazným priestorom, ktorý autori venujú explikácii týchto fyzikálnych javov, čím sa vzbudzuje dojem, že problém predstavujú v primeranej komplexnosti. O potrebe doplnenia d’alších metaforických možností Fermatovho princípu svedčia aj Chiangove poznámky k poviedkam: „Kvantovo mechanická formulácia je zaujimavá sama osebe, ale ja som dal prednost' metaforickým možnostiam klasickej verzie“29.

Ani na tomto mieste nie je nevyhnutný podrobný fyzikálny výklad, no práve zlúčenie konceptuálnych metafor SVETLO JE ČASTICA a SVETLO JE VLNA dokáže vysvetlit fyzikálny jav konzistentne so známym správaním rôznych druhov mechanického vlnenia. Predstavovanie si svetla iba ako častice dovoluje pripísat mu pevné hranice a vlastnosti jednotného objektu, neskôr entity, čo vyhovovalo aj Chiangovi v jeho poetickom zámere, pretože súčasná kvantovo-mechanická formulácia nepovažuje svetlo iba za objekt a na popis Fermatovho princípu nevyžaduje žiadne teleologické vysvetlenia.

\section{Jednotný metaforický základ v širšom kontexte Chiangovej tvorby}

Uvedomelá Chiangova autorská vol'ba medzi konceptuálnymi metaforami môže byṫ výzvou pre interpretáciu, ktorú ponúkajú Noletto a Lopes. Chiangov text totiž nie je snahou o rafinované umelecké odhal'ovanie teleologickej podstaty sveta na základe súčasného chápania prírodných javov, ako to vyplýva z ich štúdie. Uvedený výklad je aj v rozpore s Chiangovou poetikou, v ktorej autor viackrát zámerne simuluje fikčné svety s podporou už historicky vyvrátených interpretácií prírodných javov, ako to robí aj pri Fermatovom princípe $^{30}$. Rovnaký postup uplatnil v poviedke Sedemdesiatdva písem ${ }^{31}$, kde sa rozvíja dnes už absurdná teória reprodukcie organizmov - predtvarovanie, alebo tiež v príbehu s názvom Omfalos $^{32}$, v ktorom Chiang fabuluje o svete so stromami bez letokruhov a múmiami bez pupočných dierok, aby v ňom udržal logiku historickej verzie kreacionizmu, ktorá by bola konzistentná s fiktívnymi vedeckými zisteniami. Tieto postupy Chiang evidentne

28 Ibidem, s. 214-215.

29 CHIANG, Ted: Príbehy vášho života. Bratislava: Premedia, 2017, s. 225.

30 Pripomíname aj poetické využitie Sapirovej-Whorfovej hypotézy, ktorá je v súčasnosti už tiež značne revidovaná.

31 Ibidem, s. 138-186.

32 CHIANG, Ted: Výdych. Bratislava: Premedia, 2020, s. 205-233. 
nevyužíva, aby tlmočil kreacionistickú podobu nášho sveta. Jeho príbehy bývajú bud' explicitne zbavené metafyziky (Babylonská veža ${ }^{33}$ ) alebo je nepravdepodobnost̉ sveta zaháňaná do extrémov, aby bola v čo najväčšom rozpore so súčasnými vedeckými poznatkami (Delenie nulou ${ }^{34}$ ) či s každodennou ludskou skúsenostou (Peklo je neprítomnost’ Boha ${ }^{35}$ ). V týchto prípadoch sa stretávame s postavami, ktoré frustrujúco nedosahujú vytúžené ciele, no zväčša prijímajú podobu svojho fiktívneho sveta.

Analyzovaný Príbeh tvojho života evidentne nie je anomáliou v predstavenej poetike autora, ale štruktúrnou súčastou autorskej vízie. Chiang nepresviedča čitatela na teleologické interpretácie prírodných javov a prijatie metafory SVETLO JE ENTITA za hranicami literárnej špekulácie. Vedome volí z viacerých dostupných metaforických alternatív práve túto a priznáva, že účelovo potláča konceptuálne metafory kvantovej mechaniky. Robí to s cielom predostriet argumentáciu postavy, ktorá vd’aka stretnutiu s heptapodmi videla v budúcnosti smrt vlastného dietata ${ }^{36}$ a musí sa vyrovnat s danou situáciou. Chiang v poznámkach k poviedke dodáva, že hladal spôsob, ako prepojit variačné princípy s témou nevyhnutnosti, ked’ túto predstavu „skombinoval s poznámkou jednej kamarátky o jej novonarodenom dietati ${ }^{\prime 37}$.

Chápeme, že vd’aka logickej precíznosti Teda Chianga, ktorý trpezlivo predstavuje metaforickú fyzikálno-teleologickú premisu príbehu, sa výklad v umeleckom texte javí dostačujúci na literárno-filozofické závery, no ako ukazuje naša analýza, metafora, ktorú Chiang zámerne zamlčí, je pre interpretáciu jeho poviedky rovnako podstatná ako tá, ktorú predkladá. Sila prezentovanej metafory sa znásobuje aj vd’aka sugestívnosti filmovej adaptácie, ktorá sa snaží o vernost’ vzhladom na základnú konceptuálnu metaforu aj napriek istým dramatickým úpravám.

\section{Jednotný konceptuálny základ centrálnych literárnych a filmových metafor}

Hoci sa v adaptácii narúša chronológia záberov, čím sa čiastočne percepčne relativizuje kauzalita deja, nie je možné udalosti predstavit priamo simultánne, a ani sa nemožno venovat explikácii Fermatovho princípu v identickom rozsahu ako v predlohe. Filmoví tvorcovia na upevnenie hlavnej myšlienky vel’mi aktívne pracujú s konceptualizáciou času pomocou priestoru. Heptapodom pripisujú možnost odporovat gravitácii, čím narušia fixnú predstavu najuniverzálnejšieho a konceptuálne nevyhnutného pohybu v priestore - pádu. Vesmírne lode vo filme levitujú niekolko desiatok metrov nad zemou bez emitovania akéhokolvek známeho žiarenia ${ }^{38}$. Uvedenú adaptačnú adíciu ${ }^{39}$ nenachádzame

33 CHIANG, Ted: Príbehy vášho života. Bratislava: Premedia, 2017, s. 7-31.

34 Ibidem, s. 71-87.

35 Ibidem, s. 190-216.

36 Dcéra je v predlohe bezmenná, no vo filme získava palindromické meno - Hannah.

37 Ibidem, s. 255.

38 V rozpore s druhou termodynamickou vetou a „vzpierajúc sa“ entropii.

39 Adaptačný postup adície predstavuje Tibor Žilka spolu s elimináciou, kontamináciou či substitúciou. Porov. ŽILKA, Tibor: (Post)moderná literatúra a film. Nitra: Univerzita Konštantína Filozofa, 2006, s. 85. 
ani v predlohe, kde sú Chiangove vesmírne lode pochopitelne na orbite a heptapodi komunikujú nepriamo pomocou komunikačných zariadení. $\mathrm{V}$ adaptácii sú ludia po vstupe na lode chvílu v beztiažovom stave, kým sa zdanlivá prítažlivost̉ ustáli v inom smere a postavy sú schopné (z antropocentrického pohladu) kráčat po stenách.

Samozrejme, sledovanie postáv v beztiažovom stave nie je vo filmovom žánri sci-fi unikátne, no spôsob, akým je prezentovaná mechanika zakomponovaná do vizuálneho znaku, výrazne asociuje nekauzálnost̉ heptapodov, ktorí sú schopní pohybovat sa vesmírom v lubovolnom smere. Možnost nezávislého pohybu heptapodov vo filmovom priestore slúži ako metaforický podklad pre ich nezávislý pohyb v čase, podobne ako špecifické vlastnosti trajektórie svetla naznačujú v použitej teleologickej interpretácii jeho vedomé konanie. Ted Chiang konceptualizáciu času priestorom verbalizuje v interpretácii vlastností svetla a režisér Denis Villeneuve vo vizualizácii antigravitácie - oba prístupy evokujú potlačenie známych princípov kauzality.

Vd’aka kognitívnemu výskumu metafory dokážeme vyvrátit aj prípadné nadinterpretácie, ktoré by mohli uvažovat o obrátenom zámere autorov, a teda že Villeneuve by využíval premisu predlohy pre uplatnenie vlastnej metafory antigravitačných bytostí. Presvedčivé empirické dôkazy o výhradnej jednosmernosti konceptualizácie času pomocou priestoru predkladá Bergen ${ }^{40}$. Niet teda pochýb o smere asociatívneho pôsobenia na percipienta.

Dôkaz o konceptuálnej súvislosti metafor v origináli a v adaptácii možno predložit príkladmi d’alších metafor, v ktorých je vektor pohybu vopred daný, podobne, ako je to pri čase. Ide o metafory vyjadrujúce entropiu (resp. „vzpieranie sa“ entropii). Uvedomujeme si, že entropia je moderný pojem, no kognitívne vnímanie neusporiadanosti je prirodzene konceptuálne prepojené naprieč jazykom (výrazne frazeologicky a etymologicky) či rituálmi. Z antropocentrického hladiska je najevidentnejším fenoménom pre kognitívne vnímanie entropie smrt (resp. rozklad). Rituálne sa spája s priliehajúcimi prírodnými javmi $^{41}$. Základ rituálov, pravdaže, priamo súvisí s ich praktickým významom zbavenia sa tela, ale metaforicky aj s prírodnými silami, pri ktorých si ludia všímali entropické javy, a hoci ich tak nenazývali, ich metaforické podložie je konceptuálne jednotné a lísi sa skôr vo frazeologickej orientácii na pojmy informácia a entropia. Samotnú metaforu možno vnímat aj mimo súvislosti so smrtou:

ENTROPIA JE PRÚDENIE (VODY) a INFORMÁCIA JE ŠPECIÁLNY OBJEKT -, ktorý „pláva proti prúdu“.

ENTROPIA JE PRÚDENIE (VETRA) - „rozprávanie do vetra“ je zbytočné.

Orientačné metafory, ktoré pripisujú pozitívnu (v našom zmysle informačnú) hodnotu smeru hore a negatívnu (v našom zmysle entropickú) hodnotu smeru dole mapujú už Lakoff a Johnson ${ }^{42}$. Poukazujú na inak triviálne fakty v podloží konceptuálnych metafor

40 BERGEN, Benjamin K.: Louder than words: the new science of how the mind makes meaning. New York: Basic Books, 2012, s. 214.

41 Máme na mysli spálenie tela (z termodynamického hladiska je to exemplum optimum), poslanie tela po prúde rieky či sypanie popola do rieky alebo do vetra a samozrejme pochovávanie do zeme, v ktorej sa telo rozloží.

42 LAKOFF, George - JOHNSON, Mark: Metaphors We Live By. Chicago: The University of Chicago Press, 2003, s. 15-22. 
VIAC JE HORE a MENEJ JE DOLE: stíp vody nalievanej do nádoby narastá a potrava umiestnená na kopu stúpa nahor.

Informácia sa z antropocentrického pohladu v tomto prípade pohybuje proti pôsobeniu gravitácie. Zásadný význam pohybu v procese rastu sa v súčasnosti prekrýva významom zväč̌sovania sa, no pôvod konceptuálnej metafory možno presvedčivo dokladovat aj etymologicky ${ }^{43}$, a preto dopĺňame všeobecnejší metaforický základ:

ENTROPIA JE PÁD - nevyhnutný smer pohybu.

INFORMÁCIA JE RAST - protipohyb, signifikantný pohyb.

Vo svete, v ktorom sa vyvíjali kognitívne schopnosti l’udí, sa gravitácia s entropiou spája aj metaforicky, lenže Villeneuve si predstavuje Chiangove tvory vyvíjajúce sa v iných podmienkach: ich životné prostredie by si nemuselo gravitačne vynucovat vertikálne obmedzený pohyb, ale dalo by sa v ňom vol’ne pohybovat všetkými smermi. Takýmto tvorom by zásadná metafora ENTROPIA JE PÁD nič nehovorila. Villeneuve prekladá Chiangovu víziu, ktorej verbálna podoba nevyžaduje podobné extenzie, ale audiovizuálne dielo sa nevyhnutne musí s viditel'ným pohybom heptapodov a ich lodí vysporiadat, a to navyše v logickej konzistencii s ich simultánnym vnímaním času.

Veríme, že štruktúra adaptačnej realizácie pôvodných Chiangových metafor v audiovizuálnej podobe dokazuje, že redukcia kauzálnych vlastností prírodných javov - svetla v poviedke a gravitácie vo filme - neslúži autorom na to, aby fiktívnymi príbehmi prezentovali vlastné teleologické chápanie sveta, ako to vyvodzujú Noletto a Lopes. Hoci je podobné čítanie legitímne v stratégiách mŕtveho autora, my sa s ním nemôžeme stotožnit’ aj preto, že prehliada zásadné inovatívne autorské postupy.

\section{Záver}

Naším hlavným cielom bolo overit', či má kognitívny prístup k umeniu relevantnú perspektívu aj v interdisciplinárnom výskume adaptácií. Náš zámer vychádzal zo súčasného vývoja adaptačných štúdií. Ked’že kognitívny výskum má už pevné základy v priestore literatúry i filmu, overili sme kompatibilitu prístupu s tradičnými metodologickými postupmi pri skúmaní adaptácií a potvrdili sme, že kognitívny prístup je schopný vyrovnat sa aj s historicky centrálnym metodologickým problémom adaptológie - vernostou voči originálu.

$\mathrm{V}$ takto ohraničenom metodologickom priestore sme v analytickej časti príspevku dokázali praktické využitie kognitívneho prístupu, ked' sme pomocou rozboru konceptuálnych metafor poviedky Príbeh tvojho života od Teda Chianga a jeho filmovej adaptácie Proý kontakt od Denisa Villeneuvea identifikovali nadinterpretácie Noletta a Lopesa. Svoje závery sme podporili v troch hlavných líniách:

43 Lubor Králik vysvetluje, že praslovanská verzia slova rást' (*orsti) je najskôr odvodenina od indeourópskeho *er-, *or-, teda „dávat' sa do pohybu“. Porov. KRÁLIK, Lubor: Stručný etymologický slovnik slovenčiny. Bratislava: Veda, 2015, s. 492. 
1) Rozborom konceptuálnych metafor sme poukázali na fakt, že Noletto a Lopes vo svojej interpretácii subjektívne uprednostňujú metafyzické metafory, čím zároveň prehliadajú Chiangov poetický zámer.

2) Dokazujeme, že na rozdiel od interpretácie Noletta a Lopesa, je naša analýza konceptuálnych metafor konzistentná aj so širším kontextom Chiangových diel.

3) Potvrdzujeme, že v adaptácii, ktorá sa snaží o vernost̉ voči originálu, sa uplatňuje metafora s rovnakým konceptuálnym základom, a tá tiež zámerne umelecky manipuluje s podobou známych fyzikálnych javov, čím sa však nesnaží o rovnaké implikácie za hranicami textu, preto nemožno iba na základe umeleckého využitia metafyzických variácií metafor jednoznačne vyvodzovat teleologické interpretácie diel, ako to robia Noletto a Lopes.

Chiangov zámer je na osi metafyziky a fyziky už v texte prinajmenšom viacznačný, no my sa s prihliadnutím aj na predložené mimotextové dôkazy výrazne prikláňame práve k interpretáciám bez metafyzických implikácií. Ked’že k týmto odlišným záverom dospievame najmä vd’aka špecifickým možnostiam kognitívneho prístupu, potvrdzujeme jeho prínos aj vo vopred identifikovanom metodologickom priestore adaptácií.

\section{Pramene}

CHIANG, Ted: Príbehy vášho života. Bratislava: Premedia, 2017. 272 s.

CHIANG, Ted: Výdych. Bratislava: Premedia, 2020. 312 s.

VILLENEUVE, Denis: Pruý kontakt [Film]. Los Angeles, CA, 2016. 117 min.

\section{Literatúra}

BERGEN, Benjamin K.: Louder than words: the new science of how the mind makes meaning. New York: Basic Books, 2012.

BRYLLA, Catalin - KRAMER, Mette (eds.): Cognitive Theory and Documentary Film. London: Palgrave Macmillan, 2018.

BUBENÍČEK, Peter: Subversive Adaptations: Czech Literature on Screen behind the Iron Curtain. London: Palgrave Macmillan, 2017.

BUCKLAND, Warren: The Cognitive Semiotics of Film. Cambridge: Cambridge University Press, 2000.

CARTMELL, Deborah - WHELEHAN, Imelda: Screen Adaptation: Impure Cinema. London: Palgrave Macmillan, 2010.

HERMANSSON, Casie: Flogging Fidelity: In Defense of the (Un)Dead Horse. Adaptation 8, 2015, č. 2, s. $147-160$.

HUTCHEON, Linda: A Theory of Adaptation. New York: Routledge, 2006.

KRÁLIK, Lubor: Stručný etymologický slovnik slovenčiny. Bratislava: Veda, 2015.

KRISTEVA, Julie: Desire in Language: A Semiotic Approach to Literature and Art. New York: Columbia University Press, 1980. 
KUZMÍKOVÁ, Jana (ed.): Literatúra v kognitívnych súvislostiach. Bratislava: Ústav slovenskej literatúry SAV, 2014.

LAKOFF, George - JOHNSON, Mark: Metaphors We Live By. Chicago: The University of Chicago Press, 2003.

LAKOFF, George - JOHNSON, Mark: Philosophy in the Flesh: the Embodied Mind Ẽ its Challenge to Western Thought. New York: Basic Books, 1999.

LAKOFF, George - NUNEZ, Rafael E.: Where Mathematics Come From: How The Embodied Mind Brings Mathematics Into Being. New York: Basic Books, 2001.

LAKOFF, George: Women, Fire and Dangerous Things: What Categories Reveal About the Mind. Chicago: University of Chicago Press, 1990.

LARANJIRAS, C'assio C. - da SILVA, Jojomar L. - CHIAPPIN, J. R. N.: The heuristics of representation in science: the mechanisms and mathematical principles in physics of Descartes and Fermat. Revista Brasileira de Ensino de Física 39, 2017, č. 4, s. 1-15.

LEITCH, Thomas: Adaptation Studies at a Crossroads. Adaptation 1, 2008, č. 1, s. 63-77.

NOLETTO, Israel A. C. - LOPES, Sebastião Alves Teixeira: Heptapod B and the Metaphysics of Time - Hybrid Interfaces of Literature, Cinema and Science. Polifonia 25, 2018, č. 40.2, s. 206-221.

SANDERS, Julie: Adaptation and Appropriation (The New Critical Idiom). New York: Routledge, 2005.

STAM, Robert - RAENGO, Alessandra (eds.): A Companion to Literature and Film. Oxford: Blackwell Publishing Ltd, 2004.

STOCKWELL, Peter: Cognitive Poetics: An Introduction. New York: Routledge, 2002.

TURNER, Mark: The Literary Mind. New York: Oxford University Press, 1996.

ŽILKA, Tibor: (Post)moderná literatúra a film. Nitra: Univerzita Konštantína Filozofa, 2006.

\section{Mgr. Peter Getlík, PhD.}

Katedra slovakistiky, slovanských filológií a komunikácie

Filozofická fakulta, Univerzita Pavla Jozefa Šafárika v Košiciach

Šrobárova 2, 04059 Košice, SK

peter.getlik@upjs.sk

This work can be used in accordance with the Creative Commons BY-SA 4.0 International license terms and conditions (https://creativecommons.org/licenses/by-sa/4.0/legalcode). This does not apply to works or elements (such as image or photographs) that are used in the work under a contractual license or exception or limitation to relevant rights. 
